\begin{tabular}{|l|l|l|}
\hline \multicolumn{2}{|c|}{ PublisherInfo } \\
\hline \hline PublisherName & $:$ & BioMed Central \\
\hline \hline PublisherLocation & $:$ & London \\
\hline \hline PublisherImprintName & $:$ & BioMed Central \\
\hline \hline
\end{tabular}

\title{
Embryonic vs somatic mutation
}

\begin{tabular}{|l|c|l||}
\hline \multicolumn{2}{|c|}{ ArticleInfo } \\
\hline \hline ArticleID & $:$ & 4423 \\
\hline \hline ArticleDOI & $:$ & $10.1186 /$ gb-spotlight-20020315-01 \\
\hline \hline ArticleCitationID & $:$ & spotlight-20020315-01 \\
\hline \hline ArticleSequenceNumber & $:$ & 89 \\
\hline \hline ArticleCategory & $:$ & Research news \\
\hline ArticleFirstPage & $:$ & 1 \\
\hline \hline ArticleLastPage & $:$ & 2 \\
\hline \hline & & RegistrationDate : 2002-3-15 \\
\hline ArticleHistory & $:$ & OnlineDate \\
\hline \hline ArticleCopyright & $:$ & BioMed Central Ltd2002-3-15 \\
\hline \hline ArticleGrants & $:$ & \\
\hline \hline ArticleContext & $:$ & 130593311 \\
\hline \hline
\end{tabular}




\section{Jonathan B Weitzman}

Email: jonathanweitzman@hotmail.com

Discussion of the potential of using pluripotent stem cells for tissue transplantation has raised issues about the frequency and types of spontaneous mutation in these cells. In the March 19 Proceedings of the National Academy of Sciences, Rachel Cervantes and colleagues from the University of Cincinnati, Ohio, report a study of spontaneous and induced mutagenic events in murine embryonic stem (ES) cells (Proc Natl Acad Sci USA 2002, 99:3586-3590). They used a mouse model with a disrupted marker gene encoding adenine phosphoribosyltransferase (APRT), allowing analysis of uniparental disomy or loss of heterozygosity. They found that the spontaneous mutation frequencies were significantly lower (100-fold less) in ES cells than in somatic fibroblast cells. While many spontaneous mutations lead to loss of heterozygosity (LOH) in both cell types, the mechanisms differed. $\mathrm{LOH}$ in fibroblasts was the result of mitotic recombination, while the ES cells had predominantly chromosomal loss and subsequent uniparental disomy. These observations raise concerns about the use in transplantation therapy of ES cells that have been extensively cultured ex vivo

\section{References}

1. Proceedings of the National Academy of Sciences, [http://www.pnas.org]

2. University of Cincinnati, [http://www.uc.edu]

3. Adenine phosphoribosyltransferase-deficient mice develop 2,8-dihydroxyadenine nephrolithiasis. 